\title{
Pluralistic outlook as an instrument for nurturing harmony between religious groups in the city of Batam
}

\author{
Fransiskus Irwan Widjaja \\ \{irwanfiw@sttrealbatam.ac.id \\ Sekolah Tinggi Teologi Real Batam
}

\begin{abstract}
Harmony among people of different religious background is crucial concern in societal discussions lately in the context of Indonesia. The diversity of beliefs existing in Indonesia is a valuable treasure, but at the same time it presents a huge challenge for community life with the diverse available ways of thinking. The strength of each religious group tends to produce exclusivism to their respective religions. As a result, conflict between religious people is unavoidable. It is for this reason that pluralistic outlook is a major necessity in order to nurture harmonious living among people who even though are different in the religion they embrace, but are able to accept and respect one another.

Keywords: Pluralistic, harmony, Religious Group
\end{abstract}

\section{Introduction}

Indonesia is a country that guarantees the rights of each of its citizens to express their respective religions and beliefs based on the 1945 Constitution, article 28E, paragraph 1, which states: every individual has the liberty to embrace his own religion, choose education and teaching, choose an occupation, choose citizenship, choose area of residence in the territory of the State and leave it, and has the right to return. However, this guarantee is not realized in what has occurred in Indonesia lately and in Batam, particularly. Intolerant acts in relation to trust become common media news in public. The web-based daily Tempo.Com, Jakarta, Monday, August 20, 2018 reported that the results of the SETARA Institute survey showed that violations or violence pertaining to religious freedom and belief in Indonesia in 2018 rose compared to last year. SETARAreportedthat up to June 2018 there were 109 intolerance acts related to religious freedom and belief. There has been an increase in intolerance acts from year to year related to religious freedom and belief and holding worship services. On one hand, it must be acknowledged that Indonesia is one of the countries in the world that has a unique diversity including not only religious diversity, but diversity in various aspects, namely culture, language, customs, each having its own philosophy. A very striking aspect having diversity is religion; officially, there are six religions recognized by the state of Indonesia are, namely: Islam, Protestantism, Catholicism, Hinduism, Buddhism and Confucianism. Religions In Indonesia :
a. Islam
b. Protestan
c. Catholic
d. Hindu
e. Buddhism
f. Konghucu

The religious diversity aspect is the most sensitive case, being fundamental in nature in the lifeof an individual causing the most turmoil. According to records of conflicts that occurred in the Batam area and its surroundings, in 2016 there were 29 cases of social conflict occurring the 
province of Riau Archipelago. Batam City is one of the cities prone to conflicts related to ethnicity, race and religion. Therefore it can be said that Batam is a miniature of Indonesia whose population is mostly migrants from various regions and tribes in Indonesia.

Intolerance among religious groups stems from decline in pluralistic paradigm among the people. As stated Utoyo ( ... ), there are many factors that can lead to conflict between religious groups, including lack of attitude to understand and appreciate other religions and beliefs. This is what causes a person not to respect the essence and dignity of others that impacts the neglect of universal human values, thusnot producing harmonious living among one another. One reason is the lack of pluralistic perspective in society. Pluralistic view is a life calling for every human being. God in creating humans has created a pluralistic design by the diversity of gender; male and female. However in reality, the plural dimension of human existence cannot be expressed by most people, consequently bringing about intolerance in different levels of life.

\section{Research Method}

The method implemented in this study is qualitative in design, using descriptive literature on pluralism and the state of the city of Batam. This includes data on social conflictsoccurring. Direct observationswere made by the researcher as a citizen of the city of Batam, from which data is used as one of the materials complementing this research. A brief description of Batam's profile is given, covering geographical and social conditions. Batam is the largest city in the province of Riau Archipelago. The region consists of islands including the island of Batam, the island of Rempang, the island of Galang and the small islands between the strait of Singapore and the Strait of Malacca. The archipelago is connected by the famous bridge called BarelangBridge. In 2015 the population of Batam was recorded at 1,037,187 million. Batam is a special free-traderegion, suitable to its highly strategic position in a territory direcly in an international shipping route and directly next to Singapore and Malaysia. Batam is well-planned city and is the fastest growing region in Indonesia. The population continues to increase from year to year, experiencing a growth of 158 times with a rate of approximately 8 percent per year. It has a land area of $715 \mathrm{Km} 2$ while the total area is $1,575 \mathrm{Km} 2$. The population inBatam is a heterogeneous community dominated by Malay, Javanese, Batak, Minangkabau, and Chinese people. The social life reflects Malay culture and the people uphold the ideology of Bhineka Tunggal Ika (Sanscrete for 'unity in diversity'). Based on ethnic background, the population can be described as follows: 


\begin{tabular}{|l|r|}
\hline \multicolumn{1}{|c|}{ Etnis } & \multicolumn{1}{c|}{ Jumlah (\%) } \\
\hline Jawa & 26,78 \\
\hline Melayu & 17,61 \\
\hline Batak & 14,97 \\
\hline Minangkabau & 14,93 \\
\hline Tionghoa & 6,28 \\
\hline Bugis & 2,29 \\
\hline Banjar & 0,67 \\
\hline Lain-lain & 16,47 \\
\hline Sumber: Sensus Penduduk Tahun $2000^{[2]}$ \\
\hline
\end{tabular}

Whereas based on religion, the population can be divided into:

\begin{tabular}{|l|r|}
\hline \multicolumn{2}{|c|}{ Agama di Kota Batam } \\
\cline { 2 - 3 } Agama & \multicolumn{1}{|c|}{ Persen } \\
Islam & $71.14 \%$ \\
Kristen Protestan & \\
Buddha & $18.51 \%$ \\
Katolik & $6.81 \%$ \\
Konghucu & $3.32 \%$ \\
Hindu & $0.12 \%$ \\
\hline
\end{tabular}

\section{Discussion}

Pluralistic perspectiveshould not be considered the same as pluralism. Pluralistic view is the understanding that allows diversity as it is, allowing each entity to express itselfdifferentlywithout demanding a common denominator among the differences. On the other hand, the notion of pluralism does not require a concept that substitutes diversity. According to Pitoyo (2012: 67) pluralism originated from the word plural (meaning plenty), which is a concept that recognizes that there are various understandings or entities independent of one another. Each are independent entityis not bounded to one another. As a result there is no need to substitute substantial elements to substitute these ideas or various entities. Pluralistic outlook is the nature or quality that describes diversity, recognizing that the universe is created in diversity. A person who builds pluralistic strength in his perspective will create an open attitudeto all people, though having differences inparticular aspects, either in religion, ethnicity or race. 


\subsection{Pluralistic outlook produces respect for others}

One basic human need is the need to be respected. Other peripheral needs include acknowledging identity, religion and beliefs, ethnicity, race, family and others. Every individual will experience discomfort when not treated with respect. Respect that develops among people is produced by the ability to see everything under a pluralist outlook, accepting the existence of heterogeneous population in the city of Batam as a feature which exists as the will of The Creator. In the city of Batam a forum has established which called itself the Interfaith Communication Forum (FKUB) and other forums purposed for encouraging mutual harmony communication that needs to take effect to impede friction from occurring. Thus respect is established between one community and another, although some dimensions of differencesremain striking.

\subsection{Pluralistic Creation Tolerance between religious people}

The literal meaning of tolerance respecting, allowing and approving, whether it is in difference in opinions, views or beliefs (religion), habits, behavior of someone who is different from oneself. Social conduciveness produced by tolerance in a city is strongly dependent on the level of plurality of thinking of the people. Positively speaking, the heterogeneous population of Batampresents an opportunity tonurturing a pluralist mindset. Differences that become the culture of everyday part of people's life can create individual concepts that are familiar with something different. The manifestation of tolerance can be seen from the simultaneousculture that is practiced by people of various tribes, races and religions including marches of inter-religious harmony, Chinese New Year celebrations in Batam prison, declaration of interreligious harmony, tolerance expressed in religious holidays, Tolerance during Ramadan month.

\section{Conclusion}

Diversity is unavoidable in human life because variety in nature is indeed a part of God's design. Living hand in hand with people of different ethnicity, religion and race is an element that cannot be chosen by an individual. However, what needs to be built in people's lives is a culture of pluralistic thinking in order to nurture respect and tolerance among people. Batam has become one of the cities not free from social conflicts. However, amidst the tension brought about bythe occurring conflicts, efforts to develop a pluralistic culture can give birth to concrete actions to maintain unity among the heterogeneous population of Batam.

\section{Reference}


[1] Undang-undang dasar Negara Republik Indonesia 1945.

[2] https://nasional.tempo.co/read/1118802/setara-institut-intoleransi-terhadap-keyakinanmeningkat/full\&view $=$ ok

[3] https://tirto.id/ada-32-gereja-ditutup-sepanjang-5-tahun-jokowi-ke-mana-dhkD

[4] Mujiburrahman, Islam Multikultural: Hikmah, Tujuan dan keanekaragaman dalam Islam, dalam Jurnaln Addin, Vol.7, no.1 Februari 2013, 68.

[5] https://www.batamnews.co.id/berita-15883-hingga-agustus-29-konflik-sosial-terjadi-di-kepri-inipesan-kapolda.html. diakses tanggal 3 maret 2019.

[6] Tri Ratnawati, Potret pemerintahan Lokal di Indonesia di masa perubahan: Otonomi daerah tahun 2000-2006, (Jakarta: Pustaka Pelajar, 2006), 55.

[7] Marsudi Utoyo, Akar masalah konflik keagaamaan di Indonesia, dalam Jurnal Lex Librum, Vol. III, no. 1, Desember 2016, 371.

[8] https://id.wikipedia.org/wiki/Kota_Batam, diakses tanggal 3 maret 2019.

[9] Sutaryo, membangun kedaulatan Bangsa Berdasarkan nilai-nilai Pancasila: Pemberdayaan Masyarakat dalam kawasan terluar, terdepan, dan Tertinggal (3T), (Yogyakarta: Pusat Studi Pancasila UGM, 2015), 65.

[10] http://batam.tribunnews.com/2011/02/10/nuryanto-toleransi-batam-harus-jadi-contoh, diakses tanggal 5 maret 2019.

[11] Kholidia Efining Mutiara, dalam jurnal Fikrah: Jurnal ilmu aqidah dan Studi Keagamaan Vol. 4 No.2, 2016, 293.

[12] https://www.batamnews.co.id/berita-32782-5-toleransi-beragama-di-batam-yang-wajibdilestarikan.html, diakses tanggal 4 maret 2019. 